\title{
Farmer strategies to face labor shortages in Chilean agriculture
}

\author{
Estratégias dos agricultores para enfrentar a escassez de mão de obra no setor agrícola chileno
}

\author{
Verónica Aguirre $^{\mathrm{I}}$ Rodrigo Echeverría $^{\mathrm{II}}$ Clara Olmedo ${ }^{\mathrm{III}}$ Gustavo Blanco $^{\mathrm{IV}}$
}

\section{ABSTRACT}

This study analyzes the strategies that farmers in the south of Chile use to face current labor shortages and identify the variables that determine each of these strategies. A multinomial logit model and odds ratios plots with predicted probabilities were applied to a sample of 384 farmers. Interviews and focus groups were applied to specific producers, professionals and public officials. The main results show that only $32.3 \%$ of farmers declared that labor shortage is a problem. Of this percentage 52\% chose the strategy of paying better, $13.8 \%$ chose improve the workers' working conditions, $9.5 \%$ chose to mechanize, and $24.1 \%$ did not follow a strategy. The production of labor-intensive products (e.g., exportable fruit) determines the strategy of paying better; the farmer's educational level influences the strategy of improving the working conditions, and the farmer's age affects the strategy of mechanizing. However, the production of labor-intensive products exhibits the greater effect. The main disadvantage of the "pay better" strategy is that workers do not want to commit to their job.

Key words: labor shortage, agricultural labor, multinomial logit, farmers'strategies, Chilean agriculture.

\section{RESUMO}

O objetivo deste estudo foi analisar as estratégias utilizadas pelos agricultores do sul do Chile para enfrentar a escassez de mão de obra e identificar as variáveis que determinam cada uma dessas estratégias. Foram aplicados um modelo de logística multinomial e razões de chance com probabilidades previstas a uma amostra de 384 agricultores, além de entrevistas e grupos focais para determinados produtores, profissionais e funcionários públicos. Os principais resultados mostram que $32,3 \%$ dos produtores afirmaram que a escassez de mão de obra é um problema. Desse percentual, 52\% optaram pela estratégia de melhorar a remuneração, 13,8\% escolheram melhorar as condições de trabalho dos trabalhadores, 9,5\% escolheram usinar e 24,1\% não seguem nenhuma estratégia. A produção de culturas que requer mão de obra intensiva (por exemplo, a fruta exportável) escolhe a estratégia de melhorar o salário; o nível de escolaridade dos agricultores influencia a estratégia para melhorar as condições de trabalho; $e$ a idade dos agricultores determina a estratégia de usinagem. No entanto, a produção de culturas com mão de obra intensiva apresenta o maior efeito. A principal desvantagem da estratégia de "melhores salários" é que os trabalhadores não querem se comprometer com o seu trabalho.

Palavras-chave: escassez de mão de obra, mão de obra agrícola, logístico multinomial, estratégias dos agricultores, agricultura chilena.

\section{INTRODUCTION}

Chilean agriculture has experienced an important decline of workers since the middle of the 1980s, mainly caused by a competition of other economic sectors (INE, 2009). Recent reports (OTERO \& SOTO, 2012a, 2012b) have shown that labor shortage is a severe problem in the agricultural sector at a national level, estimating a deficit of 40,000 workers during 2012. Consistent with this, today it is common to read in the newspaper farmer claims regarding labor scarcity, especially during the harvest season (ROJAS, 2009). Despite this, most research has focused on the workers' problems (GATICA \& ROMAGUERA, 2005), and only few of them has

\footnotetext{
IEscuela de Graduados, Facultad de Ciencias Agrarias, Universidad Austral de Chile, Valdivia, Chile.

IIInstituto de Economía Agraria, Facultad de Ciencias Agrarias, Universidad Austral de Chile, Campus Isla Teja, Valdivia, Chile. E-mail: rodrigoecheverria@uach.cl. Autor para correspondência.

IIIInstituto de Estudios Antropológicos, Facultad de Filosofía y Humanidades, Universidad Austral de Chile, Valdivia, Chile.

${ }^{\mathrm{IV}}$ Instituto de Historia y Ciencias Sociales, Facultad de Filosofía y Humanidades, Universidad Austral de Chile, Valdivia, Chile. Received 09.10.12 Approved 03.16.13 Returned by the author 06.12.13 CR-2012-0821.R1
} 
explored this issue from the producers standpoint (FIA-PUC, 2010).

From an economic point of view, agricultural labor shortage can be explained by an increase in agricultural labor demand or by a decline of labor supply. The first case is mainly observed in labor-intensive crops, such as the fruit and vegetable production (THILMANY, 2001), while the second case is seen in capital-intensive agricultural activities, such as the dairy industry (SUSANTO et al., 2010). Although the excess and the shortage of labor exist at a prevailing wage over time, the labor market should clear, that is, a labor shortage should cause an increase in wages, so the relative labor scarcity would disappear. If wages do not increase, then the market should clear by other means.

Therefore, farmers have limited options. They can assume the higher labor costs and pay higher wages, or they can use strategies that replace labor, such as mechanization, or strategies that substitute the purely monetary incentives. The latter can include workers training, a better working infrastructure, improvements in the work environment, or special benefits to workers (e.g., stores discounts). These non-monetary measures, that are common practices used by other businesses, can be grouped as an improvement in the overall working conditions (CHIAVENATO et al., 2007).

In this context, the aim of this study is to analyze the strategies that farmers in the south of Chile use to face the labor shortage, and identify the variables that determine each of these strategies.

\section{MATERIAL AND METHODS}

This research is mainly based on a quantitative method, complemented by a qualitative approach. The quantitative methodology employs an econometric analysis that is based on data derived from face-to-face questionnaires applied to a representative sample of farmers. The sample size consisted of 384 farmers that were interviewed during the second semester of 2011. The questionnaires included questions related to the farmers' perception of the labor shortage, the strategies that farmers use for dealing with this problem, and a set of questions related to variables associated to the farmers, the farm and the socio-economic aspects of the farm system.

To analyze the variables that affect the strategies chosen by farmers, a multinomial logit, MNL, model was used (LONG \& FREESE, 2006). In this model, a farmer chooses a strategy as follows:

$$
P\left(y_{i}=m \mid x_{i}\right)=\frac{\exp \left(x_{i} \beta_{m}\right)}{1+\sum_{j=2}^{J} \exp \left(x_{i} \beta_{j}\right)}, \quad \text { for } m>1
$$

Where $P$ is the probability that a producer i chooses a strategy $m$ among a set of alternatives or categories $J$; and $x$ is the vector of independent variables that can affect this decision. The categories $J$ that a farmer can choose are: i) pay better, i.e., to pay higher salaries to workers, ii) mechanize to replace labor; iii) provide better working conditions (e.g., flexible working hours or a safe and healthy workplace), and iv) do not apply any strategy (or "none"), i.e., farmers continue in the same manner, and do not make any changes.

Based on an overall farmers' decision making framework (EDWARD-JONES, 2006), the independent variables were grouped in three groups: a) those related to the farm's labor requirements: number of permanent workers and the family labor intensity (calculated as the number of household workers out of total permanent workers); b) some specific characteristics of the farm: farm area and the type of production, which considers labor-intensive production (mainly exportable fruits), and less labor-demanding crops (such as livestock and cereal production); and c) variables related to the farmer: age, gender and educational level (years of formal education; 12 years for high school, 3 to 4 years for technical degree, and 5 or more years for a university degree), and very importantly, a labor shortage index of the area where the farm was located. In calculating the latter, the individual perception of farmers regarding the labor shortage was used for computing the average perception of labor shortage in the specific county where the farm belongs. In this way, the overall perception of labor was exogenous to a particular farmer. Although the sample included 384 farmers, data inconsistencies reduced the workable observations to 359 .

The MNL regression provides information on the significance level and the direction of the coefficients, but not about their magnitudes. Thus, marginal and discrete analyses were conducted through odds ratio plots.

The qualitative approach considered interviews and focus groups. The interviews were administered to producers, professionals and public officials of organizations related to the agricultural sector. The questions considered in these interviews were aimed to know the interviewees' perception about the role of the public programs in the agricultural labor shortage problem. The focus groups were 
conducted to selected farmers. Four focus groups were applied and their results were analyzed using a relational matrix.

\section{RESULTS AND DISCUSSION}

Table 1 shows the strategies chosen by farmers grouped by their perception regarding labor availability. Contrary to the general perception, most farmers $(67.7 \%)$ indicated that labor is not a problem (there is no labor shortage), and consequently, almost all of them $(98.4 \%)$ did not have any particular strategy. On the other hand, of those farmers that declared that labor is a problem (32.3\%), more than a half (52.6\%) chose the strategy of paying better to their workers. At a lesser degree, farmers that perceived a labor shortage chose to improve the working conditions of their workers $(13.8 \%)$ and mechanize to replace labor $(9.5 \%)$. Interestingly, a $24.1 \%$ of producers that perceive the labor shortage do not use any strategy to face the situation. Regarding the consequences derived from the scarcity of labor, $58.6 \%$ of farmers that perceive labor shortage indicated that the delay of cultivation and harvesting tasks are the main difficulties they have to handle.

Results from the MNL model are presented in table 2. The first and second columns of this table present the estimates using the category "None" as the base category, and the third column compares the category "mechanize" with the category "pay better". The comparison between other alternatives did not show statistical significance of any variable.

The only variable that showed a positive and statistically significant effect (at a $1 \%$ level) on choosing "pay better" versus choosing "none" is the production type. That is, those farmers that produce exportable fruit have higher probabilities of paying better to their workers as opposed to those farmers that choose the "none" strategy. In fact, out of the total number of producers that produce exportables, $47.5 \%$ chose the alternative of paying better. In general, fruit production is a labor intensive activity: the average fruit producer farm hires 24 workers in harvesting season, while a traditional or non-fruit producer farm (e.g., cereal production) hires only 2 workers. Therefore, in a context of labor shortage, the fastest and easiest way of hiring a large group of workers is paying better than competitors, such as other fruit producers or companies from other economic sectors. Moreover, given that exportable fruits are very perishable, there is pressure on producers to hire workers during the harvesting season. This strategy obeys to the economic solution of the supply-demand model, where the labor market clears through an increasing of wages.

The second column shows that the farmer's educational level affects positively the probability of choosing "improve working conditions" (at a $10 \%$ significant level) when compared to choosing the "none" strategy. This result suggests that producers with formal education can have a better understanding of the advantages of using strategies not linked to pay more (higher wages), such as improving the overall working conditions. The relation between this strategy and education is logical, considering that human resources management requires skills that are mainly learned through formal educational programs (CHIAVENATO et al., 2007).

Lastly, older farmers have higher probabilities of choosing "mechanize" when compared to the category "pay better". A possible explanation may be found in the continuous depopulation of Chilean southern rural areas by young people. That is, older farmers might consider

Table 1 - Strategies chosen by farmers grouped by their perception regarding labor shortage.

\begin{tabular}{|c|c|c|c|c|c|}
\hline & Pay better & mechanize & Improve working conditions & None & Total \\
\hline \multirow{3}{*}{$\begin{array}{l}\text { Labor is not a problem } \\
\text { (there is shortage) }\end{array}$} & 1 & 2 & 1 & 239 & 243 \\
\hline & $0.4 \%$ & $0.8 \%$ & $0.4 \%$ & $98.4 \%$ & $100 \%$ \\
\hline & $1.6 \%$ & $15.4 \%$ & $5.9 \%$ & $89.5 \%$ & $67.7 \%$ \\
\hline \multirow{3}{*}{$\begin{array}{l}\text { Labor is a problem } \\
\text { (there is no shortage) }\end{array}$} & 61 & 11 & 16 & 28 & 116 \\
\hline & $52.6 \%$ & $9.5 \%$ & $13.8 \%$ & $24.1 \%$ & $100 \%$ \\
\hline & $98.4 \%$ & $84.6 \%$ & $94.1 \%$ & $10.5 \%$ & $32.3 \%$ \\
\hline \multirow{3}{*}{ Total } & 62 & 13 & 17 & 267 & 359 \\
\hline & $17.3 \%$ & 3.6 & $4.7 \%$ & $74.4 \%$ & $100 \%$ \\
\hline & $100 \%$ & $100 \%$ & $100 \%$ & $100 \%$ & $100 \%$ \\
\hline
\end{tabular}


Table 2 - Results from the multinomial logit model.

\begin{tabular}{lccc}
\hline & Pay better (Based: None) & Improve working conditions (Base: None) & Mechanize (Base: Pay better) \\
\hline Age & $-0.016(0.011)$ & $0.017(0.195)$ & $0.044^{*}(0.024)$ \\
Education & $0.042(0.047)$ & $0.137^{*}(0.195)$ & $0.099(0.103)$ \\
Sex & $-0.202(0.311)$ & $-0.237(0.081)$ & $-0.098(0.680)$ \\
Production type & $0.869^{* *}(0.321)$ & $0.186(0.541)$ & $-0.764(0.730)$ \\
Permanent workers & $-0.054(0.086)$ & $0.307(0.587)$ & $-0.038(0.126)$ \\
Household labor intensity & $-1.001(0.817)$ & $-1.634(0.108)$ & $-0.689(1.467)$ \\
Labor shortage index & $7.785(4.818)$ & $8.979(1.215)$ & $-3.963(10.855)$ \\
Farm area & $-0.003(0.003)$ & $-0.008(8.686)$ & $0.007(0.004)$ \\
Intercept & $-0.536(1.415)$ & $-4.017(2.428)$ & $-4.038(2.986)$ \\
\hline
\end{tabular}

Log Likelihood: -258.1333; LR Chi²(24): 49.54; Pseudo R2: 0.0876

$*, * *$ significant at $10 \%$ and $5 \%$, respectively.

investing in mechanization given that they do not count on a generational replacement (BLANCO \& $\mathrm{KOCH}, 2008)$.

For analyzing the magnitude of the coefficients obtained in the MNL model, figure 1 presents a graphical analysis of odds ratios (factor changes that are independent of the value at which the rest of the variables are analyzed). The letters represent the three alternatives ("Pay better", P; "Mechanize", M; "Improve working conditions", I; and "None", N). The line linking two letters in each variable represents no statistical difference on the probability of choosing those categories. Besides, the size of the letters is proportional to the magnitude of the discrete change of the variables (LONG \& FREESE, 2006).

The main result of this analysis is that shifting production from domestic-oriented products to export-oriented products, with all variables held at their means, increases the probability of paying better much more than the probability of choosing any of the other categories, and importantly, neither age nor education show this magnitude on the probability of choosing a particular category.

As a summary of the quantitative analysis, it is possible to conclude that "paying better" is the most frequent strategy that farmers choose to deal with the labor shortage, and this strategy is dominated in labor intensive crops, such as exportable fruit production. At a lesser degree, improving the working conditions of workers is mainly driven by more educated farmers. Mechanization is an alternative for more experienced farmers, although this strategy is insignificant when compared to better pay.

Results from the qualitative approach are consistent with the results obtained in the quantitative analysis. In the focus groups farmers stated that the strategy to face the labor shortage is simply paying more. However, according to farmers, this strategy results in workers without commitment, who just expect a better payment. Farmers said that under this scenario, where salaries dominate the contractual relationship, the worker will maintain a position of "work while you are well paid, and do what pleases you", which is a behavior that has been well studied in other industries (SCHVARSTEIN \& LEOPOLD, 2005). As a consequence of this situation, workers could leave the farm at any time if they consider that the payment is not enough.

The results from the interviews to public officials and professionals indicate that they perceive a labor shortage in all regions of study, which differs from the results obtained in the quantitative analysis. Indeed, the quantitative approach shows that almost half of farmers $(45.9 \%)$ that declared that labor was a problem, were exporters (fruit producers). However, this small share of producers $(12.5 \%$ of the entire sample) represents a huge impact on the labor market. Out of the 359 producers that were analyzed, exporters (fruit producers) demanded a total of 2.352 workers (98 farms times an average of 24 workers per farm) while traditional producers demanded only 522 workers (261 farms times an average of 2 workers per farm). Thus, $12.5 \%$ (45 fruit producers) demand twice the number of workers that demands the entire set of traditional producers (261 producers, which represents a $72.7 \%$ of the sample). Therefore, the perception of the labor shortage problem stated by public officials and professionals is broader because it not only includes the number of farms involved, but also the number of workers that are affected.

According to national statistics, farmlabor shortage has been steadily rising since 2010 and reached a record deficit of 39.437 workers during 


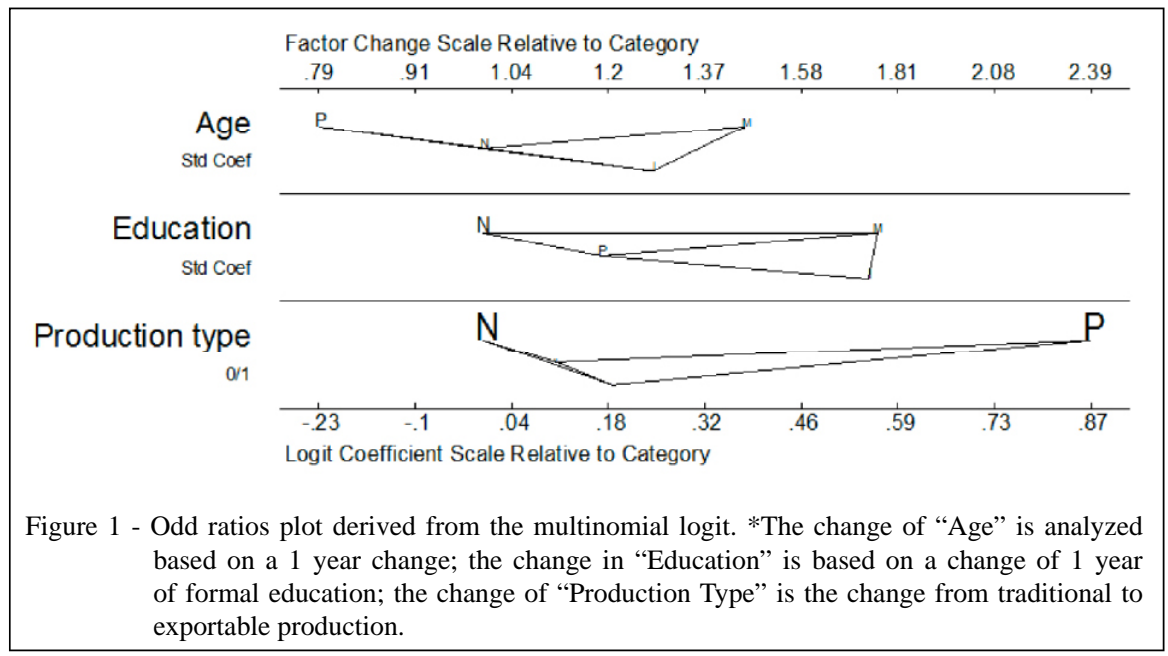

the last Chilean summer of 2012 (OTERO \& SOTO, 2012). As a result, the government has made efforts to attract workers to the agricultural sector, such as strengthening the county agencies designed to attract labor (OMIL agencies) or relaxing the maximum number of foreign workers that can work in Chilean agriculture. However, the interviewed public officials declared that these efforts have not been efficient in the area of study, which is coherent with the perception of farmers, who predominantly declared that they do not know or are not clear about how state programs can help to alleviate the problem.

The little attention and priority that the labor-shortage issue receives in the two regions of study can be explained by the geographic distribution of the agricultural unemployment. The main labor-shortage is produced in the north and central zones of the country, wherein workers have moved from agriculture to other fast growing economic areas, such as the mining and construction sectors (OTERO \& SOTO, $2012 \mathrm{~b}$ ). However, in the two regions of study, labor unemployment has not raised as much as in the rest of the country, which would explain the gap between the national awareness about the labor-shortage problem and the local efforts to face it. However, if the national tendency continues (the mining and construction sectors keep attracting workers), the labor-shortage problem will be a serious issue for both farmers and public officials across all Chilean regions, requiring them to implement efficient policies and strategies to confront the labor scarcity.

\section{CONCLUSION}

Despite that labor shortage is evident in the Chilean agricultural sector, only a third of farmers perceive the labor scarcity. In this scenario, the strategy that farmers have followed is merely attract workers paying them higher wages, especially in the case of farmers that produce labor-intensive crops, such as the exportable fruit production. Other strategies, such as improving the working conditions of workers, are used at a lesser degree, mainly by farmers that have a higher educational level. This would suggest that it is possible to replace the monetary incentives with non-monetary stimuli, but this would require skills (training in human resources management) that the majority of farmers do not have.

\section{ACKNOWLEDGEMENTS} n.11100228.

This research is part of the FONDECYT project

\section{SOURCES AND MANUFACTURES}

a. Questionnaires applied to farmers, focus groups, and interviews. b. Statistical program Stata, ver. 10.1.

\section{BIOETHICS AND BIOSSECURITY COMMITTEE}

The present study was approved by the ethic committee of Universidad Austral de Chile (UACh) and the National Commission for Scientific and Technological Research (FONDECYT)

\section{REFERENCES}

BLANCO, G.; KOCH, T. UACH, Estudio de Prospectiva Regional en el marco de la elaboración de la estrategia de desarrollo regional de Los Ríos. 2008. 59f. Available from: <http://www.goredelosrios.cl/directory/files/estrategia/web/ Anexo2SistematizacionTalleresExpertosUACH.pdf $>$. Accessed: Aug. 30, 2012. 
CHIAVENATO, I. et al. Administración de Recursos Humanos Madrid: McGraw-Hill, 2007. 699p.

EDWARD-JONES, G. Modelling farmer decision-making: concepts, progress and challenges. Animal Science, v.82, p.783790, 2006.

FIA-PUC (FUNDACIÓN PARA LA INNOVACIÓN AGRARIA PONTIFICIA UNIVERSIDAD CATÓLICADE CHILE). Estrategias para superar la escasez de mano de obra agrícola de temporada en labores de alta demanda. 2010. Available from: http: $</ / 200.111 .68 .14 / \mathrm{gsdl} /$ collect/iniciati/index/assoc/HASH4cb1.dir/ FIA-PI-C-2007-1-A-011_IF.pdf>. Accessed: Aug. 30, 2012.

GATICA, J.; ROMAGUERA, P. El mercado laboral en Chile: nuevos temas y desafíos. Oficina Internacional del Trabajo. 2005. 33p. Available from: <http://www.oitchile.cl/pdf/ publicaciones/ele/elec016.pdf>. Accessed: Aug. 30, 2012.

INE (INSTITUTO NACIONAL DE ESTADÍSTICAS). Cambios estructurales en la agricultura chilena. Análisis intercensal 1976-1997-2007. Santiago, 2009. Available from: <http://www.ine. cl/canales/chile_estadistico/estadisticas_agropecuarias/2009/07/ cambios_estructurales.pdf>. Accessed: Aug. 30, 2012.

LONG, J. S.; FREESE, J. Regression models for categorical dependent variables using Stata. California: StataCorp LP, 2006. $527 \mathrm{p}$.

OTERO, M; SOTO, S. Análisis del mercado laboral agrícola y sus sectores competitivos. In: OFICINA DE ESTUDIOS Y POLÍTICAS AGRARIAS, ODEPA, 2012a. 18p. Available from: <http://www.odepa.gob.cl//odepaweb/publicaciones/doc/8330.
pdf;jsessionid=4E058054629EA5729E54F6ABF2D1F2DB >. Accessed: Dec. 13, 2012.

OTERO, M; SOTO, S. Catastro Laboral Agrícola. Oficina de Estudios y Políticas agrarias, ODEPA. 2012b. 28p. Available from: <http://www.odepa.gob.cl//odepaweb/ publicaciones/ doc/6623.pdf;jsessionid=7F877C28A66F7E5DEF4BB9689ED67 A7D>. Accessed: Dec. 13, 2012.

ROJAS, A. De la abundancia a la escasez: La evolución del mercado de trabajo en la modernización fruticola. 2009. 23f. Thesis (Tesis de Licenciatura en Historia) - Universidad de Chile. Available from: <http://www.cybertesis.cl/tesis/uchile/2009/rojas_ an/html/index.html>. Accessed: Aug. 30, 2012.

SCHVARSTEIN, L.; LEOPOLD, L. Trabajo y subjetividad: Entre lo existente y lo necesario. Buenos Aires: Paidós, 2005. 295p.

SUSANTO, D. et al. Immigration policy, foreign agricultural labor, and exit intentions in the United States dairy industry. Journal of Dairy Science, v.93, p.1774-1781, 2010. Available from: <http://web.ebscohost.com/ehost/ pdfviewer/pdfviewer?vid=4\&sid=b5b60a62-fca6-428d-9a24a2988814c32b\%40sessionmgr104\&hid=123>. Accessed: Apr. 29, 2013. doi: $10.3168 /$ jds.2009-2733.

THILMANY, D.D. Farm labor trends and management in Washington State. Journal of Agribusiness, v.19, p.1-15, 2001. Available from: <http://web.ebscohost.com.webproxy. uach.cl $: 2048 /$ ehost $/$ detail vid $=4 \&$ hid $=24 \&$ sid $=299$ e $882 \mathrm{f}-\mathrm{d} 14 \mathrm{~b}-$ 4533-a43e-fb574644c938\%40sessionmgr14\&bdata=Jmxhbmc9 ZXMmc210ZT1laG9zdC1saXZl\#db=lah\&AN=20033047443>. Accessed: Aug. 30, 2012. 